\title{
Tobacco Associated Factors of Adolescents
}

\section{Fatores Associados dos Adolescentes ao Tabagismo}

\author{
Mariana Marra Sepulveda ${ }^{\text {a }}$ Olga Dillenburg Rezer ${ }^{\text {a; }}$ Maristela Prado e Silva Nazario*b; Juliana Santi Sagin Pinto \\ Bergamim; ; Marcly Schelles de Lima ${ }^{\mathrm{d}}$; Ariane Hidalgo Mansano Pletsch ${ }^{\mathrm{e}}$
}

\author{
aState Public Health School, Family Health Post-Graduate Degree. MT, Brazil. \\ ${ }^{\mathrm{b} C u i a b a ́ ~ I n s t i t u t e ~ o f ~ E d u c a t i o n ~ a n d ~ C u l t u r e . ~ M T, ~ B r a z i l . ~}$ \\ ${ }^{c}$ Cuiabá Institute of Education and Culture. MT, Brazil. \\ dJuara Municipal Department of Health. MT, Brazil. \\ eUniversity of Cuiabá. MT, Brazil. \\ *E-mail: maristelaprado@hotmail.com \\ Recebido em: 27/01/2020 \\ Aprovado em: 30/03/2020
}

\begin{abstract}
Currently, smoking is considered a serious public health problem and is considered the greatest avoidable cause of illness, disability and death. Several studies, over time, have concluded the relationship of smoking to serious diseases that are responsible for anti-smoking government policies worldwide. There are many advances in tobacco prevention and smoking cessation, but data on smoking deaths are still alarming. Brazil is considered a great inspiration for other countries when it comes to these policies, just as other countries served as inspiration for Brazil, such as Canada. Children and adolescents are a group that is very vulnerable to smoking and therefore are considered a priority when it comes to prevention. In light of the above, a bibliographical review was carried out with the objectives of contextualizing the problem of smoking and of identifying the factors that lead adolescents to use tobacco. The study shows that smoking is considered one of several risk situations that the adolescent is exposed in this phase of so many transformations. Most authors point to curiosity as the major factor that leads the adolescent to smoking and the parents and friends smokers as main influences for the initiation of this habit.
\end{abstract}

Keywords: Tobacco. Tobacco Use Disorder. Young.

\section{Resumo}

Atualmente o tabagismo é considerado um sério problema de saúde pública, sendo considerada a maior causa evitável de doenças, invalidez e morte. Diversos estudos, ao longo do tempo, foram concluindo a relação do hábito tabágico às doenças graves que são responsáveis por politicas governamentais antitabagismo em todo mundo. Muitos são os avanços para a prevenção do tabagismo, bem como para o auxílio na cessação deste hábito, porém ainda são alarmantes os dados relacionados ao óbito de fumantes. O Brasil é considerado uma grande inspiração para outros países quando se trata dessas políticas, assim como outros países serviram de inspiração para o Brasil, como o Canadá. As crianças e os adolescentes formam um grupo muito vulnerável ao tabagismo e por este motivo são considerados prioridade quando se trata de prevenção. Frente ao exposto, realizou-se uma revisão bibliográfica com os objetivos de contextualizar a problemática do tabagismo e de identificar os fatores que levam os adolescentes a fazerem uso do tabaco. O estudo mostra que o tabagismo é considerado uma das várias situações de risco que o adolescente é exposto nessa fase de tantas transformações. A maioria dos autores apontam a curiosidade como o maior fator que leva o adolescente ao tabagismo e os pais e amigos fumantes como principais influências para a iniciação deste hábito.

Palavras-chave: Tabaco. Tabagimo. Saúde do Adolescente.

\section{Introduction}

Smoking iconsidered the main preventable cause of illness, disability, and death. Around one-third of the adult world population is smokers, of which $48 \%$ are men and $10 \%$ are women, with a worrying trend of increased female consumption. Tobacco use causes about five million deaths per year, which could double by $2030^{1}$.

Some groups are considered to be of greater risk when it comes to smoking. Among them adolescents are included ${ }^{2}$. Moura $^{3}$ points out that regardless of age limits, adolescence is characterized as a socially concept, which refers to individuals in profound physical, psychological and behavioral transformations.
Adolescence is an individual parameter and relates to biopsychosocial transformation of sexual development and maturation, suffering social and cultural influences

Based on the above considerations, these adolescents are vulnerable to smoking and are exposed to the risks of this practice that is harmful to health. Among the evils that cigarette causes to the young group are the deleterious effects on the developing organism and the potentiality of a long-term dependence ${ }^{2}$.

Therefore, this study aimed to contextualize the problem of smoking during adolescence and to identify in the literature the factors that lead adolescents to tobacco use. 


\section{Development}

\subsection{Methodology}

To perform the bibliographical survey, scientific articles were searched through research in electronic databases in the Virtual Health Library (VHL-adolec), which has the collections of journals, texts and scientific articles and in the SciELO, PubMed, Lilacs database. The descriptors used to identify the articles in the databases were: Tobacco, smoking, adolescents and factors. The selected articles respected the period from 2000 to 2018 .

\subsubsection{About adolescence}

The Statute of the Child and the Adolescent (ECA) delimits adolescence as the age range between 12 and 18 years. Whereas the World Health Organization (who) restricts between 10 and 19 years, considering the period between 1 and 24 years as youth ${ }^{5}$.

Malta et al. ${ }^{6}$ consider that adolescence refers to a transition period from childhood to adulthood, in which physical, cognitive, emotional, social and hormonal changes occur. In this phase of life, autonomy and independence grow in relation to the family and experimentation with new behaviors and experiences, which may represent important risk factors for health, among which smoking is highlighted.

Regarding the psychological characteristics in adolescence, the restructuring or search for a new identity is mainly emphasized, which makes the adolescent move away from the family, seeking a new identity that is built, conscious and unconsciously, in a slow and painful process of drawing up mourning for the loss of the child's body, child identity and parents' relationship ${ }^{7}$.

\subsubsection{On tobacco}

As described in Brazil (1996) the use of tobacco came about in the year 1000 B.C., in the indigenous societies of Central America, in magical religious rituals aimed at purifying, contemplating, protecting and strengthening the wicked warriors, and believing that it had the power to predict the future. The plant probably reached Brazil by the migration of Tupis-Guarani tribes ${ }^{9}$.

Initially, used for curative purposes, through pipe, it spread rapidly, reaching Asia and Africa in the 17th century. In the following century, the fashion of aspirating snuff came to light, to which medicinal qualities were attributed, because the queen of France, Catherine de Médicis, used it to relieve her migraines. In the 19th century, the use of cigar began, through Spain reaching the whole of Europe, the United States and other continents, and was used to demonstrate ostentation. Around 1840 to 1850 , the first descriptions of men and women smoking cigarettes appeared, but only after World War I (1914 to 1918 ) they had a major expansion?

Its use spread throughout the world from the mid-20th century, with the help of advanced advertising and marketing techniques that developed at this time. Since the 1960s, the first scientific reports that related cigarette smoking to the smoker getting sick became apparent ${ }^{9}$.

\subsubsection{The constituents of the tobacco and its consequences for the smoker's body}

One of the chemical constituents of tobacco is nicotine, but when tobacco is grown with fertilizers and pesticides, processed in the form of cigarettes and finally burned, many other constituents are aggregated. The three most important elements found in cigarette smoke are tar, carbon monoxide and nicotine ${ }^{10}$.

Arsenic, nickel, benzopyrene, cadmium, lead are some of the substances contained in tar and are responsible for cancer ${ }^{8}$.

Carbon monoxide is a gas that results from the burning of the matter, easily passes from the pulmonary alveoli to the bloodstream, combining with hemoglobin, resulting in oxygen deficiency to the organism. When the cardiac system detects insufficient oxygen levels, the heart may start working poorly and trigger a heart attack $^{10}$.

Nicotine is the substance responsible for causing chemical dependence and therefore damage to the smoker's health. Among the known effects of this substance is its action in the central nervous system, causing increased mood, decreased appetite and muscle relaxation ${ }^{11}$.

Repeated exposure of this smoked substance results in rapid tolerance and smokers experience less physical and psychological effects throughout the day. Many smokers report that the first cigarette of the day is the tatiest, this is due to the fact that the person remained without smoking during the night ${ }^{9}$.

When smokers become aware of the harm that tobacco causes and resolves to quit smoking, they face a great difficulty, often accompanied by withdrawal syndrome

Abstinence syndrome occurs shortly after the last cigarette, because nicotine is easily excreted and is characterized by the desire to smoke, restlessness, irritation, difficulty in concentration, depressive feelings, daytime sleepiness and difficulty sleeping at night, and increased appetite, as well as physical symptoms such as decreased heart rate and decreased blood pressure ${ }^{7}$.

Carvalho ${ }^{13}$ adds that cigarette causes 26 fatal diseases, 11 types of cancer, six cardiovascular diseases, five respiratory and four pediatric diseases, shortening the life of those who smoke 15 cigarettes a day by five years, in addition to causing heroin-like dependence.

Among the main causes of death in Brazil are neoplasias, ischemic heart diseases, cerebrovascular diseases and pulmonary diseases ${ }^{14}$.

Lung cancer is the most frequent among cancers among smokers, appearing in the twenty-thirty-year period of tobacco use, and may vary according to the amount and type of smoked cigarette. The probability of mouth cancer is also much higher 
among smokers when compared to nonsmokers ${ }^{12}$.

\subsubsection{The consequences of smoking for non-smokers}

Smokers are not the only ones exposed to cigarette smoke and consequently to the damage that it entails. According to Brazil $^{9}$ non-smokers exposed to it are called passive smokers and adds that particles of cigarette smoke are found anywhere they smoke, especially in enclosed, residential or public places, rapidly exceeding the concentration of the air pollution level, resulting in a drop in air pollution quality in the environment.

Short-term damages to passive smokers can be considered eye irritation, nasal manifestations, cough, headache and increased allergic and cardiac problems, and long-term injuries can be considered to reduce respiratory capacity, respiratory infections, increase in the risk of atherosclerosis, acute myocardial infarction and cancer ${ }^{8}$.

Maternal smoking not only causes damage to the baby during her intrauterine life, such as growth restriction, low weight, premature membrane rupture, and premature placental detachment. Its effects also affect the postnatal period, including the early termination of lactation and its consequences on the child's development.

Children of low age are also important targets of smoking, because they have a higher sensitivity to this pollution and their bronchial trees easily suffer toxic and irritating effects of smoking. Children of smoking parents have three times or more chances of suffering from rhinitis, bronchial wheezing, asthma, acute bronchitis, bronchiolitis, pneumonia and bronchopneumonia than children of abstemized parents 9 .

Santos ${ }^{16}$ complement by reporting that the airways of children under five years of age are immature and more sensitive to the effects of smoking, and it is not necessary to have a person smoking immediately close to them in order for the smoke to be inhaled, the existence of pollutants in the environment is sufficient to be the smoking habit of a few minutes or hours for children to come into contact with smoke. The effects on these children exposed to smoking are infections and other recurrent respiratory diseases and a greater predisposition to pulmonary diseases in the future.

\subsubsection{Factors that favor smoking during adolescence}

The initiation of smoking during adolescence takes place earlier in major cities and the best way to combat this evil is through education, starting at home. Since most smokers experience cigarettes before the age of 18 (about 90\%), the main objective is to keep them away from this percentage ${ }^{16}$.

The causes of smoking are diverse, among them the imitation is mentioned, in which children and young people imitate adults, usually parents, because they consider them superior ${ }^{9}$.

Lara ${ }^{17}$ mentions that before people were led to addiction by the best of examples such as Hollywood stereotypical models and the aggressive propaganda of cigarette industries that had previously been informed by the federal government. She also reports that smoking was already considered elegant and refined in belle epoque and that smoking symbolized virility at the beginning of the century and soon afterwards, the women's emancipation.

For Bouer ${ }^{18}$, friends and parents are responsible for opening the way for young people to experience and also to influence consumption patterns. The cigarette becomes a class code and smoking a ritual, in the ballads, parties. Smoking after dinner also turns routine at home and thus cigarette is incorporated into people's habits.

Moraes $^{12}$ agrees that people often smoke to manifest maturity, virility, or even a subtle way of countering standards. The pleasure of forbidden thing motivates young people to try cigarettes, mainly with the help of misleading and abusive advertising in favor of the product, which, for years, were impregnated in the human subjective, implanting the idea that smoking compares pleasure, good taste, intelligence, masculinity and success.

Cigarette has become a symbol that represents the transition from childhood to a more independant world, and that is why the habit of smoking grows a lot among adolescents, even in countries where there is a drop in consumption among adults

Tobacco consumption usually starts in adolescence and the earlier its onset, the greater the severity of dependence. This habit is associated with low school income, the smoking of older siblings, parents and friends, as already mentioned ${ }^{13}$.

The high levels of social acceptability of tobacco products and the availability and ease of access to products are also factors that contribute to the initiation of smoking among young people

A study carried out in Belém do Pará, among high school students, confirms that smoking in adolescence has a great influence on parents, siblings and friends of smokers and that the ease of cigarette purchases, the personal perception of school income, the dialog on smoking in the family environment and the socioeconomic level of families are also important factors

In agreement, studies ${ }^{8,19}$ indicate the imitation of the behavior of adults, parents and popular idols, the encouragement offered by propaganda and the pressure of group colleagues as the main factors that favor smoking initiation.

Abramovay and Castro $^{21}$ in a study involving children and young people from primary and secondary education in 14 Brazilian capitals, showed that smoking friends are really a great influence for smoking initiation and emphasize that, according to statements collected with students, the places of first cigarette experimentation are at parties, shows and bars. They add that young people admit that, in order to feel intimate and accepted, they adopt the group's standard behaviors as a habit of smoking.

In Cuiabá-MT, a study on the factors associated with smoking initiation in public and private school adolescents 
indicated the lower level of schooling of the mother, the lower socioeconomic level of the family, studying in public school, attending 7 th, 8 th series and 1 st year of the second degree, studying at night, having been failed at school, having smoking friends and siblings and belonging to the higher age groups as factors associated with cigarette experimentation among adolescents ${ }^{22}$.

A study carried out with 102 young people from a school in Salvador-BA identified that among smokers the percentage of close smokers who also smoked was $90.9 \%$ and indicated curiosity as the main factor that led them to try the first cigarette

In Portugal, in addition to the factors already highlighted in other studies that indicate smoking parents and friends as determinants for the onset of smoking, the school is also mentioned as a place where it is the most common place to smoke ${ }^{24}$.

According to the National Cancer Institute, young people deserve special attention because they are more vulnerable to the influence of propaganda and the behavior of social groups. It is also associated the age of initiation of regular use of cigarettes with the severity of dependence in the future and states that, in general, there are no notable differences in the percentage of smokers between women and men in Brazil

\subsection{Results}

Twenty scientific articles were selected, the analysis of which allowed us to find divergent studies on the factors that lead adolescents to smoking. The results of the bibliographic research were elucidated in Chart 1.

Table 1 - Results found in 20 selected articles (2000-2018)

\begin{tabular}{|c|c|c|c|}
\hline Categories & Results Found & $\begin{array}{c}\text { Number } \\
\text { of } \\
\text { Articles } \\
\%\end{array}$ & $\begin{array}{l}\text { Total of } \\
\text { articles }\end{array}$ \\
\hline \multirow{10}{*}{$\begin{array}{c}\text { Category 1: } \\
\text { Factors } \\
\text { associated } \\
\text { with cigarette } \\
\text { experimentation } \\
\text { among } \\
\text { adolescents. }\end{array}$} & Curiosity & $25 \%$ & 05 \\
\hline & Low school performance & $15 \%$ & 03 \\
\hline & $\begin{array}{l}\text { Studying in public } \\
\text { school }\end{array}$ & $15 \%$ & 03 \\
\hline & $\begin{array}{l}\text { Lower maternal } \\
\text { education; }\end{array}$ & $15 \%$ & 03 \\
\hline & $\begin{array}{l}\text { Low adolescent } \\
\text { education; }\end{array}$ & $15 \%$ & 03 \\
\hline & $\begin{array}{l}\text { Lower socioeconomic } \\
\text { level of the family; }\end{array}$ & $15 \%$ & 03 \\
\hline & $\begin{array}{l}\text { Studying in the night } \\
\text { period; }\end{array}$ & $10 \%$ & 02 \\
\hline & $\begin{array}{l}\text { Having already been } \\
\text { failed in school; }\end{array}$ & $15 \%$ & 03 \\
\hline & $\begin{array}{l}\text { Belonging to higher age } \\
\text { groups; }\end{array}$ & $15 \%$ & 03 \\
\hline & Parents Separation & $15 \%$ & 03 \\
\hline \multirow{4}{*}{$\begin{array}{l}\text { Category 2: } \\
\text { Influences } \\
\text { that favor } \\
\text { smoking during } \\
\text { adolescence }\end{array}$} & Having smoking parents; & $35 \%$ & 07 \\
\hline & Having smoking friends; & $20 \%$ & 04 \\
\hline & $\begin{array}{l}\text { Having smoking } \\
\text { siblings; }\end{array}$ & $15 \%$ & 03 \\
\hline & Advertisement/ media & $15 \%$ & 03 \\
\hline
\end{tabular}

Source: Research data.
According to category 1 (factors associated with cigarette experimentation among adolescents), one fourth of the studies refers to curiosity as the major factor associated with cigarette experimentation among adolescents.

Regarding category 2 (influences that favor smoking during adolescence), it is observed that the influence of smoking parents is prominent in $35 \%$ of the articles studied, followed by the influence of smoking friends, found in $20 \%$.

\subsection{Discussion}

For Nogueira and Silva ${ }^{11}$ adolescence is a phase of experimentation and there are several factors that lead adolescents to experience tobacco adolescence is a phase of experimentation and acceptance before their peer, it is a constant search for himself or herself and his or her identity. Factors that lead a young person to start cigarette use include curiosity about the product, imitation of adult behavior, need for self-affirmation and encouragement provided by advertising.

Through a study carried out with young people in SalvadorBA, Almeida and Mussi ${ }^{23}$ found that almost all the students who were smokers presented close smokers and that almost half of these young people started smoking by curiosity. In 102 young people from a school in Salvador, the prevalence of smokers was $10.8 \%$. Among the young smokers, there was a predominance of males $(63.6 \%)$ and of those who were next smokers $(90.9 \%)$, an average age of 18.2 years and of tobacco experimentation of 13.4 years, almost half in the 1 st year of the collegiate group (45.5\%) and with a self-reported skin color (45.5\%). Most young smokers received family (81.8\%) and school (72.7\%) guidance on health damage (90.9\%) and it was difficult to quit smoking (54,6\%), but few (36.4\%) knew about the benefits of smoking cessation. Almost half had been smoking for more than three years and began the habit as a matter of curiosity.

The result of another study carried out with students in Belém-PA corroborates the previous study, pointing out that most of the smokers indicate their own curiosity as the main cause of smoking, followed by the influences of friends, parents, brothers and media and adds that easier access to cigarette purchases also acts as an incentive to maintain the smoking habit, since it makes the young "self-sufficient" to buy cigarettes at the moment the biological and/or psychosocial need arises $^{20}$.

Smoking adolescents are highly likely to become smoking adults, thus increasing the risk of morbidity and mortality associated with smoking.

Barreto et al. ${ }^{25}$ identified several factors related to the smoking habit of young people and cited in their research the prevalence of regular smokers was $6.3 \%$, being statistically higher in the elderly, of brown color, whose mothers have less schooling, students in public schools and presenting the studied behaviors.

Silva $^{22}$ also points out that the mother's lower level of 
schooling and belonging to higher age groups are factors that lead the young person to smoking, in addition to the family lower economic level, studying in public school, to be attending 7 th, 8 th series and the 1 st year of the 2 nd grade, studying in the night period and having already been failed in the school.

Silva et al. ${ }^{26}$ confirmed that the highest concentration of smokers lies in the population with the lowest level of education. The results of the study showed significant differences in the prevalence of smoking in the Brazilian state capitals population. The highest prevalence of smokers found in the present study was among individuals with low level of education $^{26}$.

In a study carried out by Horta et al. ${ }^{27}$ it can be observed that the adolescent's school failing is considered a smoking triggering factor the prevalence of smoking was also higher among adolescents who were not attending school or who had already failed the school.

Agreeing with the authors mentioned above, Silva et al. ${ }^{28}$ also associated the young person' failing at the school in a study that established that the prevalence of smoking in the school population of Maceió children and adolescents is $2.4 \%$ and that it increases with age, with the night shift and the history of repetence, as well as previous experimentation with cigarettes.

Malcon et al. ${ }^{29}$ present in their results of a survey conducted in South America risk factors for smoking among adolescents that fit into the two categories cited in the present study, the risk factors identified were: sex, adolescent age, socioeconomic level, school income, presence of smoking among parents, siblings and friends, separation of parents and work.

Other studies corroborate and complement the factors that lead adolescents to smoking, emphasizing the low level of education and wages not sufficient to satisfy basic needs, intra and interfamily conflicts, lack of discipline, lack of intimacy between parents and children, distance from parents, lack of dialog among family members and low expectations of children's educational future are risk factors that lead to the induction of young people and/or adolescents to the use of licit drugs

Abreu et al. ${ }^{31}$ affirm the individual characteristics that were associated with smoking habit in the univariate analysis were higher age, lower education, male gender, and alcohol consumption considered at risk.

There are studies ${ }^{29,33}$ that reveal the other factors that lead to smoking in adolescence as low income in studies, school dropout and paid work, which are also factors related to smoking in adolescence. Family disadjustment, separation of parents and housing with people other than biological parents, low self-esteem and depression are conditions that increase the smoking likelihood among adolescents.

Viana et al. ${ }^{34}$ observed that the consumption of cigarettes by schoolchildren was associated with statistical significance to the variables: Age greater than 15 years, male sex, not having religion, working, beginning of sexual activities and experiencing domestic violence.

Menezes et al. ${ }^{35}$ a study carried out in Londrina, Paraná, Brazil, with 517 students from the 9th year of the Fundamental School of Public Schools, they observed that the age of 15 years or older and having smoking friends constitute risk factors for the regular use of cigarettes among adolescents.

Regarding Category 2, which is related to the influences that favor smoking during adolescence.

Silva $^{22}$ explains about the responsibility of the family and the school for the citizen formation. Family has its share of responsibility for the citizen integral formation with the school, because it is the school that decides early on what their children need to learn, what institutions they should attend, what is needed to know to make decisions that will benefit them in the future.

About smoking in adolescence Silva ${ }^{22}$ states that trying to better understand the extent of this problem among the young population, numerous studies have sought to identify the possible determinant and important factors in smoking initiation. Studies show that there are a range of complex and interrelated factors, varying between individuals and populations.

In the literature, the parents' habit of smoking is often identified as a risk factor for smoking during adolescence. Some studies have shown an association of smoking in adolescence with the smoking habit of parents (father and mother $)^{22,29}$.

Silva $^{22}$ points out that the presence of one or more smokers at home, usually parents, in addition to the various harm done to health, still serves as a negative influence for the child, that from early notice the smokers and tends to imitate them during their lifetime.

A study carried out with 2036 adolescents, Fraga et al. ${ }^{24}$ concluded that having friends who smoke is an important factor for adolescents to experience or start smoking, reinforcing the importance of proximity relationships. Smoking parents are also indicated as the major determinant of the onset of habit among young people and that the prevalence of smoking children is higher when living in a single-parent family with a smoking parent:

Machado Neto et al. ${ }^{36}$ concluded in their research that alcohol consumption and the influence of people living in the young person presented a strong association with cigarette experimentation; and that parental smoking and the influence of the media on tobacco products have increased the chances of consumption of this substance.

On the influence of parents, a study ${ }^{37}$ shows that, concerning parental smoking, there is a significantly high risk of smoking and the use of illicit drugs by adolescents when both the father and mother are smokers. The risk is 
reduced when only the father or mother smokes. The habit of smoking parents does not seem to have any relation to the use of alcohol by adolescents in this study ${ }^{37}$.

In this context, Abreu et al. $^{31}$ complete that the characteristics of smoking in the family, having smoking brother and father and mother smokers were associated with smoking in adolescents or young adults. All factors about cigarette consumption in the social group were significantly associated with smoking among young people.

Nogueira and Silva ${ }^{11}$ agree when they report that when the young person is questioned, he or she points out that his or her reference as a smoker is a friend or his or her parents. Currently, the tobacco industries perceive in the young person a market reserve, thus directing the advertisements to this public. It is known that the incidence of cigarette use increases among adolescents exposed to other young smokers due to the need to be accepted in the group.

According to Pinto and Ribeiro ${ }^{20}$ it is through friends that the adolescent, often, obtains the first cigarette and that the fact that he or she obtained the first cigarette with his or her friends demonstrates that the beginning of smoking is associated to the social students' relationships, where the need to identify with their peers and being part of the group, associated with curiosity, characteristics inherent to adolescence are decisive in this process.

Another influence that favors smoking in adolescence is propaganda and the media. Promotion and advertising of tobacco products to young people are essential so that the tobacco industry is to be able to maintain and expand its sales. Tobacco is the $2^{\mathrm{a}}$ most widely used drug among young people in the world, due to the facilities and incentives to obtain the product, among them the low cost. Seducing young people is part of a strategy adopted by all tobacco campaigns, aiming to replenish the ranks of those who stop smoking or die, by other consumers who will be the regular ones of tomorrow ${ }^{22}$.

\section{Conclusion}

This literature review study allowed us to observe that there are many factors and influences that lead adolescents to smoking, such as low school income, studying in public school, lower mother's schooling, the family lower socioeconomic level, low adolescent's schooling, studying in the night period. having already been failed in school, belonging to higher age groups, parents separation, having smoking siblings and influence of propaganda and the media, but the main factor is curiosity and the main influences are those of smoking parents and friends.

The results found in this study make it possible for managers and health professionals to plan actions for making decisions regarding The Public Policies of Adolescent Health in search of the prevention and control of smoking among adolescents.

Since prevention must be a priority when it comes to the population health, it is up to the government managers, states and municipalities to invest even more in Basic Care, which offers primary care to the citizen. The strategy begins with the training of health team professionals to develop, with competence, preventive actions with children and adolescents. The focus should be on the medium- and long-term harm of smoking, as well as the exposure of the compound constituents to the cigarette product and its consequences for the human body of smokers and passive smokers. At the same time, smoking cessation should be an active strategy among health teams, thus benefiting many smokers and reducing smoking injuries.

Therefore, even with Brazil being considered an example when the subject is anti-smoking policy and strategies, there is still much to be done to combat this evil in the country.

\section{References}

1. Brasil. Ministério da Saúde. Secretaria de Atenção à Saúde. Departamento de Atenção Básica. Doenças respiratórias crônicas. Brasília: MS; 2010.

2. Duncan BB, Schmidt MI, Giugliani ERJ. Medicina ambulatorial: condutas de atenção primária baseadas em evidências. Porto Alegre: Artmed; 2004.

3. Moura JRA, Figueiredo IGA, Santos TNC, Sousa EC, Vieira TF, Lima SEA. Conversas de adolescentes sobre drogas e sexualidade: um relato de experiência. Revinter 2015;8(2):117-30.

4. Brasil. Ministério da Saúde. Secretaria de Políticas de Saúde. Área Técnica de Saúde do Adolescente e do Jovem. Marco legal: saúde, um direito dos adolescentes. Brasília: MS; 2005.

5. Brasil. Ministério da Educação. Secretaria Especial dos Direitos Humanos. Estatuto da Criança e do Adolescente. Brasília: MEC; 2005.

6. Malta DC, Sardinha LMV, Mendes I, Barreto SM, Giatti L, Castro IRR, et al. Prevalência de fatores de risco e proteção de doenças crônicas não transmissíveis em adolescentes: resultados da Pesquisa Nacional de Saúde do Escolar (PeNSE), Brasil, 2009. Ciênc Saúde Coletiva 2010;15:3009-19. doi: http://dx.doi.org/10.1590/S1413-81232010000800002

7. Marques ACPR, Campana A, Gigliotti AP, Lourenço MTC, Ferreira MP, Laranjeira R. Consenso sobre o tratamento da dependência de nicotina. Rev Bras Psiquiatr 2001;23(4):20014

8. São Paulo. Secretaria de Estado da Educação. Tá na roda: uma conversa sobre drogas. São Paulo: J. Shoslna; 2003.

9. Brasil. Ministério da Saúde. Instituto Nacional do Câncer. Falando sobre tabagismo. Rio de Janeiro: INCA; 1996.

10. Claret M. O que você deve saber sobre tabagismo. São Paulo: Martin Claret; 2001.

11. Nogueira KT, Silva CMFM. Tabagismo em adolescentes numa escola da rede pública do estado do Rio de Janeiro. Adolesc Saude 2004;1(4):6-10.

12. Moraes CA. Responsabilidade civil das empresas tabagistas. Curitiba: Juruá; 2009.

13. Carvalho MC. O cigarro. São Paulo: Publifolha; 2001.

14. Brasil. Ministério da Saúde. Instituto Nacional de Câncer. Ações de enfermagem para o controle do câncer: uma proposta de interação ensino-serviço. Rio de Janeiro: INCA; 
2008.

15. Brasil. Ministério da Saúde. Instituto Nacional do Câncer. A situação do tabagismo no Brasil: dados dos inquéritos do Sistema Internacional de Vigilância, da Organização Mundial da Saúde, realizados no Brasil, entre 2002 e 2009. Rio de Janeiro: INCA; 2011.

16. Santos SR. Apague o cigarro da sua vida: com métodos científicos para auxiliar o fumante a parar de fumar. São Paulo: Alaúde; 2006.

17. Lara PRC. Fumo sim, e daí? aos militantes antitabagistas e outros chatos-de-galocha que estiverem de plantão. Campo Grande: Letra Livre; 2000.

18. Bouer J. Álcool, cigarro e drogas. São Paulo: Panda Books; 2004.

19. Brasil. Ministério da Saúde. Instituto Nacional do Câncer. Coordenação nacional de Controle do Tabagismo e Prevenção Primária do Câncer. Crescendo livre de tabaco. Rio de Janeiro: INCA; 1998.

20. Pinto DS, Ribeiro SA. Variáveis relacionadas à iniciação do tabagismo entre estudantes do ensino médio de escola pública e particular na cidade de Belém - PA. J Bras Pneumol 2007;33(5):55-64. doi: http://dx.doi.org/10.1590/S180637132007000500011

21. Abramovay M, Castro MG. Drogas nas escolas. Brasília: UNESCO; 2005.

22. Silva MP, Silva RMVG, Botelho C. Fatores associados à experimentação do cigarro em adolescentes. J Bras Pneumol 2008;34:927-35

23. Almeida AF, Mussi FC. Tabagismo: conhecimentos, atitudes, hábitos e grau de dependência de jovens fumantes em Salvador. Rev Esc Enferm 2006;40(4):456-63. doi: http:// dx.doi.org/10.1590/S0080-62342006000400002.

24. Fraga S, Ramos E, Barros H. Uso de tabaco por estudantes adolescentes portugueses e fatores associados. Rev Saúde Pública 2006;40(4):620-6. doi: http://dx.doi.org/10.1590/ S0034-89102006000500010.

25. Barreto SM, Giatti L, Casado L, Moura L, Crespo C, Malta DC. Exposição ao tabagismo entre escolares no Brasil. Ciênc Saúde Coletiva 2010;15(suppl.2):3027-34. doi: http://dx.doi. org/10.1590/S1413-81232010000800007.

26. Silva GA, Valente JG, Almeida LM, Moura EC, Malta DC. Tabagismo e escolaridade no Brasil. Rev Saúde Pública 2009;43(Supl 2):48-56.

27. Horta BL, Calheiros P, Pinheiro RT, Tomasi E, Amaral KC. Tabagismo em adolescentes de área urbana na região sul do
Brasil. Rev Saúde Pública 2001;35(2):159-164.

28. Silva MAM, Rivera IR, Carvalho ACC, Guerra Junior AH, Moreira TCA. Prevalência e variáveis associadas ao hábito de fumar em crianças e adolescentes. J Pediatr 2006;82(5):365-70. doi: http://dx.doi.org/10.1590/S002175572006000600010 .

29. Malcon MC, Menezes AMB, Maia MFS, Chatkin M, Victora CG. Prevalência e fatores de risco para tabagismo em adolescentes na América do Sul: uma revisão sistemática da literatura. Rev Panam Salud Publica/Pan Am J Public Health 2003;13(4):222-8.

30. Moreno RS, Ventura RN, Bretas JRS. Ambiente familiar e consumo de álcool e tabaco entre adolescentes. Rev Paul Pediatr 2009;27(4):354-60. doi: http://dx.doi.org/10.1590/ S0103-05822009000400002

31. Abreu MNS, Souza CF, Caiaffa WT. Tabagismo entre adolescentes e adultos jovens de Belo Horizonte, Minas Gerais, Brasil: influência do entorno familiar e grupo social. Cad Saúde Pública 2011;27(5):935-3.

32. bortoluzzi MC, kehrig RT, Loguercio AD, Traebert JL. Prevalência e perfil dos usuários de tabaco de população adulta em cidade do Sul do Brasil (Joaçaba, SC). Ciênc Saúde Coletiva 2011;16(3): 1953-9. doi: http://dx.doi.org/10.1590/ S1413-81232011000300029.

33. Wunsch Filho V, Mirra AP, Lopez RVM, Antunes LF. Tabagismo e câncer no Brasil: evidências e perspectivas. Rev Bras Epidemiol 2010;13(2):175-87. doi: http://dx.doi. org/10.1590/S1415-790X2010000200001.

34. Viana TBP, Camargo CL, Gomes NP, Felzemburgh RDM, Mota RS, Lima CCOJ. Factors associated with cigarette smoking among public school adolescents. Rev Esc Enferm USP 2018;52:e03320. doi: http://dx.doi.org/10.1590/s1980220x2017019403320

35. Menezes AHR, Dalmas JC, Scarinci IC, Maciel SM, Cardelli AAM. Fatores associados ao uso regular de cigarros por adolescentes estudantes de escolas públicas de Londrina, Paraná, Brasil. Cad. Saúde Pública 2014;30(4):774-84.

36. Machado Neto AS, Andrade TM, Napoli C, Abdon LCSL, Garcia MR, Bastos FI. Determinantes da experimentação do cigarro e do início precoce do tabagismo entre adolescentes escolares em Salvador (BA). J Bras Pneumol 2010;36(6):674-82. doi: http://dx.doi.org/10.1590/ S1806-37132010000600003.

37. Horta RL, Horta BL, Pinheiro RT. Drogas: famílias que protegem e que expõe adolescentes ao risco. J Bras Psiquiatr 2006;55(4):268-72. 